\title{
nature
}

\section{What happens after the crash?}

\section{The US budget is almost certain to be cut by now. What happens next rests with the reserve banks. Their best plan is to extend credit to the United States, the world's largest debtor.}

Washington's will to put the United States on a sounder economic footing seems to be wilting as memories of the recent crash on Wall Street fade. The US government has only until tomorrow, 20 November, to avoid the automatic imposition of spending cuts amounting to $\$ 23,000$ million under the provisions of the modified Gramm-Rudman Act, and seems bent on prolonging until the last minute its four-week internal wrangle about a more intelligent way of reducing the federal deficit.

Part of the trouble is that the next presidential election campaign is already well under way, with the result that neither party wishes to be seen responsible for either higher taxes or reduced spending (except that the Democrats would cheerfully cut the defence budget). It also seems to be the case that the Congress and the administration have lost heart by recognizing that the object of the exercise is in part symbolic: the danger that there will be an economic recession argues that this is not the time to cut the federal deficit (see Nature 330, 1; 1987), but the general opinion has emerged that foreigners will not continue to finance the US trade deficit (witness the falling US dollar) without a demonstration that the United States can quickly come to a simple decision on the federal deficit. It seems not to be fully appreciated elsewhere that the tortuous negotiations between the White House and the Congress are aimed at an outline agreement only, and that it will fall to the appropriations committees to decide the details (and to backslide, given half a chance). That is why Gramm-Rudman may be the best solution.

Meanwhile, the next step in the resolution of the incipient financial crisis needs more attention than it has been given. The major trading partners of the United States, who call themselves the Group of Seven (or G7 for short) have agreed that there should be an international discussion on the aftermath of the stock-market crash, but only when the deficit negotiations in Washington are finished - probably next week. There must be many among the central bankers and finance ministers present who will wish that one among them were nimble enough to pull a financial rabbit out of a hat in the manner of J.M. Keynes, whose proposals at the Bretton Woods conference held sway for more than a quarter of a century (until 1972). Alas, Keynes has been overtaken by events, especially the financial interdependence of industrialized states.

The problem for the next G7 meeting is simply stated. The industrial economies operate factories, farms and service industries for whose products there are potential customers in plenty. For most of the past decade, potential customers have also had the funds with which to make purchases on a scale sufficient to enlarge economic activity everywhere, if unevenly. The obvious snag is that some customers have been purchasing with money borrowed from elsewhere; US customers of the international economy, in particular, have been spending the savings of prudent Japanese and, to a lesser extent, prudent West Germans. Some of the lenders have ended up owning physical assets in the United States, and may not be too worried now, but others, with the US dollar now sharply devalued, know they can get their money back only in kind; if they want cash, their loans will not be fully requited. So they have turned shy.

The need, in these circumstances, is to find a mechanism for sustaining the global demand for goods and services while accomodating the peculiar circumstances of the United States (which must nevertheless eventually balance its books either by increased taxes or by increased voluntary savings). The solution, if there is one, must be a novel device by which governments internationally make up for the unwillingness of private individuals and institutions to finance the trade imbalances that have accumulated, and which cannot suddenly be halted except traumatically. The central banks must find a way to lend each other funds.

In principle, this is what Keynes's International Monetary Fund is for, but the ground rules are too restrictive for present circumstances, while the membership is inappropriately wide. A better instrument is the Bank for International Settlements (BIS), G7's own clearing bank, which exists in Basle, Switzerland, largely as a paper institution for settling reserve banks' debts with each other. Why not turn BIS into an institution that functions fully as an international reserve bank, the lender of last resort? The debtor nations in particular would then find their freedom to execute monetary policy compromised by the terms on which they were compelled to borrow. Either interest rates or currency conversions would be less easily controlled than at present. But that would be better than the prospect of another long recession which everybody seems anxious to avoid. Certainly it would be a more substantial contribution to stability than the agreement, earlier this year, to sustain the US dollar at a level too high for logic to accomodate.

\section{British research muddle}

\section{Are British arrangements for science policy} constitutionally improper?

WHAT is to be made of a government that allows one group of taxpayers to purchase the right to influence the spending of other people's taxes? Not much, it will be thought. But that, on the face of things, is what is about to happen with the British government's encouragement of the new Centre for the Exploitation of Science and Technology (see p. 196), to which eighteen industrial companies have made financial contributions. For although the organizers of the new centre insist that they do not wish to force Britain's beleagured academic researchers into more evidently applied research, there is every reason to fear that the new centre's work will shape the overall pattern of research supported by the research councils, the government's chief source of discretionary expenditure on basic research in academic institutions. The constitutional propriety of this arrangement needs more attention than it has been given. There would be ructions if a committee appointed by, say, insurance companies were to be given an inside track in determining the pattern of spending on the British National Health Service.

This is how malign influence could be exerted. The centre's objective is to survey the developing field of science and to draw attention to fields appearing to offer industrial opportunities. Much will depend on the character and calibre of the people who will eventually staff the centre, but the occasion could well arise 